УДК: 340.13:002:355.4(470:477+571)

ТУРЧАК О.В.

https://orcid.org/0000-0002-1806-5289

НАДРАГА М.С.

https://orcid.org/0000-0003-2247-6061

https://doi.org/10.33577/2313-5603.32.2019.206-216

\title{
НОРМАТИВНО-ПРАВОВА БАЗА ЩОДО ЗБЕРЕЖЕННЯ ДОКУМЕНТІВ ТА МАТЕРІАЛІВ РОСІЙСЬКО-УКРАЇНСЬКОЇ ВІЙНИ
}

Сьогодні гостро стоїть потреба у збереженні джерел до вивчення історії російсько-української війни. Серед основних джерелознавчих комплексів матеріали засобів масової інформації, інтернет-ресурси, усноісторичні джерела і, що найважливіше, матеріали діловодства військових частин та підрозділів Збройних Сил України. У статті проведено аналіз нормативно-правової бази у сфері збереження документів, що висвітлюють перебіг російсько-української війни. Основним видом таких документальних комплексів $\epsilon$ матеріали діловодства військових частин Збройних Сил, що беруть участь у проведенні АТО та ООС. Нормативно-правова база щодо збереження документів та матеріалів російськоукраїнської війни є достатньою, однак, слід звернути увагу на формування системного підходу у цьому питанні. Вживати заходи, в тому числі і правотворчого характеру, щодо недопущення втрат такого роду історичних джерел, що містять надзвичайно цінний і унікальний фактологічний багаж.

Ключові слова: російсько-українська війна, нормативно-правова база, джерельна база.

Постановка проблеми. Проблема фіксації та збереження джерел до вивчення сучасної російсько-української війни актуалізується необхідністю у майбутньому всестороннього об'єктивного дослідження їі подій, фактів і явищ.

Актуальність дослідження зумовлена тим, що джерельна база цих історичних досліджень є надзвичайно різноманітною та презентабельною. Серед основних джерелознавчих комплексів вказаної проблематики слід виділити матеріали засобів масової інформації,

Турчак Олександр Володимирович, доктор юридичних наук, доцент, начальник науково-дослідної лабораторії (військово-історичних досліджень) Наукового центру Сухопутних військ Національної академії сухопутних військ імені гетьмана Петра Сагайдачного, м. Львів.

Надрага Марта Степанівна, кандидат історичних наук, провідний науковий співробітник науково-дослідної лабораторії (військово-історичних досліджень) Наукового центру Сухопугних військ Національної академії сухопутних військ імені гетьмана Петра Сагайдачного, м. Львів.

(C) Турчак О.В., Надрага М.С., 2019 
телебачення, радіо та преси, інтернет-ресурси, усноісторичні джерела i, що найважливіше, документальні комплекси, зокрема, матеріали діловодства військових частин та підрозділів Збройних Сил України.

Метою статmі $\epsilon$ аналіз нормативно-правової бази у сфері збереження документів новітньої російсько-української війни.

Виклад основного матеріалу. Аналіз сучасного стану 3MI та періодики показує, що їх діяльність здебільшого грунтується на принципах демократичності та плюралізму. Як наслідок - зростання ïx ролі у висвітленні актуальних проблем сьогодення, зокрема подій російсько-української війни, активного зближення 3 історикокультурним процесом.

Засоби масової інформації постають одним із унікальних феноменів громадсько-політичного життя, виступають не лише як історичне джерело, а й як суб'єкт історичного процесу. Усі види ЗМІ є важливим інструментом впливу на свідомість людей, дієвим знаряддям інформації. Періодична преса стала частиною національного історичного процесу.

Процеси історичного розвитку незалежної України концентруються, нагромаджуються та віддзеркалюються на шпальтах вітчизняних періодичних видань. Преса набуває статусу важливого історичного джерела, засобу формування громадської думки та практичного втілення окреслених рішень. Джерельні та концептуальні парадигми періодичних видань є своєрідним каталізатором при визначенні правильності обраного державного курсу. В цьому виявляється й інший бік джерелознавчої цінності періодики. Відомо, що багато істориків-джерелознавців пресу вважають таким собі «щоденником часу», який і за формою, і за змістом відповідає тому чи іншому суспільству.

Водночас досвід новітніх збройних конфліктів показує, що одними з важливих механізмів війни стають не тільки зміни у військовій справі, але й інформаційна складова.

Публікації ЗМІ мають особливості, які слід враховувати при використанні їх як історичного джерела. Однією з головних є їх „відносна достовірність”, обумовлена суб'єктивізмом журналістів або недостатнім рівнем їх професійної підготовки, впливом різноманітних об'єктивних і суб'єктивних факторів (цензура, тиск з боку засновників, комерційне або політичне замовлення, інформаційні запити аудиторії і т.д.). Це змушує дослідників ретельно перевіряти факти, зіставляти їх з відомостями інших джерел, враховувати авторство матеріалів, умови їх створення тощо. 
Побутує думка, що через великий обсяг публікацій, які місцеві газети передруковують із центральних видань, вони не можуть розглядатися в якості самостійного джерела. Однак досить часто ця інформація більш адресна, набагато ближче до життєвих реалій.

При аналізі матеріалів ЗМІ слід брати до уваги, що окрім явної фактологічної інформації в кожному джерелі міститься прихований зміст. Проводячи історичний аналіз, необхідно визначити достовірність наявних фактів і висновків, обгрунтованість інтерпретації тексту з урахуванням історичних реалій і умов його створення. Тому, як звертають увагу окремі дослідники засобів масової інформації, вдаючись до історичного аналізу такого роду джерел, слід застосовувати метод «читання між рядків».

Найбільш поширеними та доступними широкому загалу виступають інтернет-ресурси як історичне джерело. Входячи в інтернетпростір, людина має можливість отримувати інформацію з різних сфер знань, оперативно (навіть в режимі реального часу) знайомитися 3 новинами.

Починаючи з середини 1990-х років розпочався процес проникнення інтернет-технологій у професійну діяльність істориків, паралельно з розширенням доступу в глобальну мережу почали створюватися електронні ресурси 3 історії. Відбувається осмислення пов'язаних з цим джерелознавчих проблем. В мережі створюються спеціалізовані науково-освітні ресурси з історії.

Використовуючи ресурси Інтернету для вирішення дослідницьких, зокрема джерелознавчих, завдань слід мати на увазі специфіку представлення інформації в мережі. Зокрема, серед іншого виникає питання про те, наскільки можна довіряти цій інформації. Навіть у спеціалізованих електронних ресурсах часто не вказується, хто автор текстів, звідки взяті фотоілюстрації, як отримані фактологічні дані тощо. Таким чином, дослідник не має гарантій якості одержуваної інформації. Необхідно зберігати критичне ставлення до інтернет-ресурсів.

На сьогодні історичне дослідження не зможе базуватися тільки на тих джерелах, які представлені в електронному вигляді. Специфічним для них $є$ питання автентичності, первинності документа, оскільки сучасні технології дозволяють створювати копії, абсолютно подібні оригіналам.

Новим різновидом історичного джерела можна вважати блоги, які $є$ широким джерелом для дослідження проблематики сучасних подій російсько-українського протиборства. За своєю природою 
вони схожі на ЗМІ. Блог може служити комплексним джерелом сам по собі і в той же час бути інструментом у роботі історика.

Чимало важливої і унікальної інформації несе у собі реконструкція подій війни у спогадах іiі учасників, в матеріалах інтерв'ю методом «усної історії».

В останні роки прослідковується зростання інтересу до усної історії як історичного джерела, і зокрема стосовно сучасної російсько-української війни. Дослідження на основі методології усної історії урізноманітнюються тематично, зростає їх якісний рівень, вдосконалюється методика і методологія дослідження, налагоджується співпраця між науковцями та громадськими активістами тощо. Використовуючи ці джерела, слід брати до уваги низку супутніх факторів.

Зокрема, звертаємо увагу на можливе зменшення числа безпосередніх свідків та учасників найбільш важливих подій російськоукраїнської війни, спогади яких становлять особливий інтерес. Інколи доводиться мати справу з вторинними спогадами.

Все більшої актуальності набуває дискусія про те, коли подія стає минулим, історією, яку можна і треба вивчати у форматі усноісторичних досліджень.

Сьогодні можливі ситуації, коли усні джерела за відсутності інших письмових документів були визнані доказами у судових процесах і стали підставою для відновлення історичної справедливості по відношенню до вже минулих подій. Власне усні свідчення (спогади) дозволяють розкрити страшну правду про події новітньої війни, психологічні та фізичні травми, яких зазнали учасники цих подій i, як результат, соціальну дезадаптацію колишніх вихованців інтернатів.

Ці свідчення, зокрема, дають підставу для висунення звинувачень РФ на різноманітних платформах світових і європейських міжнародних організацій, що врешті призведе до визнання Росії агресором, продовження широкомасштабних санкцій.

Слід зазначити про певну обмеженість уявлень, що дає саме лише вивчення офіційних документів.

У контексті усноісторичних джерел до вивчення історії російсько-української війни актуальними $є$ питання однобічності. Постає проблема відсутності свідчень тих, хто був призвідниками та співучасниками військових злочинів і трагедій. Адже нинішня 
усна історія репрезентує досвід жертв історичних катаклізмів, сторонніх свідків подій. Спогади винуватців вкрай рідкісні.

На часі $€$ розширення тематичного спектру усноісторичних студій з тим, щоб охопити менш драматичні періоди та сторони життя військових і цивільного населення у зоні бойових дій, зосередившись на героїчних сторінках цих кривавих подій.

На тлі революційних і воєнних подій в українців загострилася потреба віднайти історичне опертя для власної громадянської національної ідентичності. Будучи сучасниками історичні зміни в нинішній Україні, люди прагнуть зрозуміти їх і себе через пізнання критичних моментів.

Основним видом документальних комплексів, що слугує джерелом до вивчення історії російсько-української війни є матеріали діловодства військових частин та підрозділів Збройних Сил України, що беруть безпосередню участь у проведенні АТО та ООС.

Одним із перших нормативно-правових актів, що регламентував процедуру ведення діловодства у Збройних Силах України, виданий напередодні російсько-української війни, був Наказ Генерального штабу Збройних Сил України від 16 вересня 2013 року № 200. Ним затверджена «Інструкція з діловодства в Збройних Силах України» (Наказ ГШ ЗСУ №200). Інструкцією встановлювалися вимоги щодо функціонування підрозділів, що займаються діловодством у Збройних Сила України. Ця діяльність включає підготовку, реєстрацію, облік, зберігання і контроль за виконанням відповідних документів. Відповідальними за організацію діловодства визначаються командири військових частин. Вони ж є відповідальними за збереження службових документів, інформації, функціонування системи захисту документаційного фонду від незаконного доступу, втрату і несанкціоноване знищення документів, порушення правил користування ними. Заступники командира військової частини відповідають за зміст, якість підготовки та оформлення документів, що розробляються. Організація загального діловодства покладається на відповідні структурні підрозділи частин. Командири частин зобов'язані систематично контролювати стан діловодства. Один раз на рік стан діловодства перевіряється спеціальною комісією, призначеною наказом командира. Серед іншого звертається увага на наявність поточних та архівних справ і документів, вибірково перевіряється наявність найбільш важливих документів.

На командирів частин покладений обов'язок своєчасно передавати до Галузевого державного архіву Міністерства оборони 
України документи, граничний строк зберігання яких у військовій частині закінчився і які не використовуються в практичній роботі. На службу діловодства покладаються завдання проведення експертизи цінності документів, формування справ, складання їх описів, передачу на державне зберігання до ГДАМО України, організації зберігання документаційного фонду військової частини, користування ним, підготовки заявки до Плану-графіка передачі документів до ГДАМО України. Тут, власне, мова йде і про ті документи, що $\epsilon$ джерелами до висвітлення Антитерористичної операції та операції Об'єднаних сил на Сході України. Однак, як засвідчує практика, ці вимоги не завжди дотримувалися. Чимало документів такого роду 3 тих чи інших причин втрачені назавжди.

Одним із видів такого роду документів є історичний формуляр документ, в якому, зокрема, відображається бойова діяльність військової частини, важливі події, стан бойової підготовки, військової дисципліни та інші відомості.

Згідно з Інструкцією з метою збереження архівних документів у військових частинах створювалися архівні підрозділи. Серед їх завдань була підготовка та передавання документів до ГДАМО. Надання справ у тимчасове користування здійснювалося не більше як на один місяць. Вилучення документа зі справи зі строком зберігання постійно та тривалого (понад 10 років) суворо заборонялося.

Військова частина зобов'язана забезпечити зберігання архівних документів відповідно до встановлених правил, а після закінчення граничних строків зберігання і передавання їх до ГДАМО. Документом встановлювався порядок підготовки документів до передавання на державне зберігання.

Була чітко прописана процедура знищення документів у бойових умовах. Військові частини, що беруть участь у бойових діях, не повинні накопичувати документи. Відпрацьовані і непотрібні документи повинні знищуватись на місці, а документи, що мають наукову, історико-культурну та практичну цінність, відправлятися на зберігання до архіву.

Усі посадові особи військової частини зобов'язані здійснювати заходи щодо недопущення втрат, псування, незаконного знищення документів. Втрата, незаконне знищення, псування документів тягне за собою адміністративну відповідальність відповідно до Кодексу України про адміністративні правопорушення.

Законом України „Про Національний архівний фонд та архівні установи" встановлено, що забороняється знищення документів без 
попереднього проведення експертизи їх цінності. В ході проведення експертизи цінності документів експертні комісії керуються типовими та галузевими переліками видів документів 3 встановленими строками їх зберігання. Забороняється вилучення документів із Національного архівного фонду за мотивами конфіденційності чи таємності інформації, що міститься в них та із політичних чи ідеологічних міркувань (Закон України № 316-VIII).

Сьомого квітня 2017 року начальником Генерального штабу Збройних Сил України був виданий наказ № 124, який затвердив нову Інструкцію з діловодства у Збройних Силах України та визнавав таким, що втратив чинність, наказ Генерального штабу від 16 вересня 2013 року № 200 „Про затвердження Інструкції 3 діловодства у Збройних Силах України" (зі змінами) (Наказ ГШ ЗСУ № 124).

Затверджена Інструкція розроблена відповідно до постанов Кабінету Міністрів України від 30 листопада 2011 року № 1242 „Про затвердження Типової інструкції з діловодства у центральних органах виконавчої влади, Раді міністрів Автономної Республіки Крим, місцевих органах виконавчої влади" (зі змінами) та від 19 жовтня 2016 року № 736 „Про затвердження Типової інструкції про порядок ведення обліку, зберігання, використання і знищення документів та інших матеріальних носіїв інформації, що містять службову інформацію".

Назагал ця Інструкція повторює основні положення попередньої Інструкції у сфері ведення діловодства. Згідно документом Галузевий державний архів Міністерства оборони України іменується Архівом Міністерства оборони України.

3 точки зору формування документів, що можуть стати джерелами до вивчення історії АТО і ООС, певний інтерес викликає Наказ Міністерства оборони України від 17.06.2013 року № 404 (Наказ МОУ № 4). Ним затверджено Перелік документів, що утворюються в діяльності Міністерства оборони України та Збройних Сил України, із зазначенням строків їх зберігання. Зокрема, у Покажчику видів документів передбачено: Акти 3 питань розслідування бойових дій військ (сил), бойових втрат особового складу, Висновки з питань планів операцій, Виписки з журналів бойових дій, Відомості обліку військовополонених, співвідношення сил і сторін, Відомості щодо бойових дій військ (сил), 
втрат супротивника, захоплених підприємств, складів та баз противника, Довідки про противника, Довідки з питань планів операцій, Бойові донесення, Донесення про бойові дії військ (сил), про втрати противника, про розслідування бойових дій військ (сил), розвідувальні донесення, Доповіді з оцінкою обстановки та перспектив бойових дій, про бойові втрати особового складу, Журнали бойових дій, обліку та реєстрації бойових дій, Історичні довідки, формуляри, різноманітні карти, Книги з історії з'єднань, військових частин, Огляди бойових дій родів військ, преси противника, Оперативні зведення і повідомлення, Описи театрів та районів бойових дій, Плани бойових дій тощо. Строк зберігання для документів, що утворюються в особливий період, у період виконання спеціальних урядових завдань, у тому числі операцій 3 підтримання миру, з'єднань, військових частин, військових навчальних закладів, установ, організацій Збройних Сил України та підприємств, що належать до сфери управління Міністерства оборони України, як правило, визначено на постійно.

Відповідно до Постанови Кабінету Міністрів України від 12 квітня 1995р. № 276 ,Про створення Галузевого державного архіву Міністерства оборони" був створений Галузевий державний архів Міністерства оборони для постійного зберігання документів Національного архівного фонду, що утворюються в процесі розбудови і діяльності Збройних Сил України. У лютому 2013 року затверджено „Положення про Галузевий державний архів Міністерства оборони України".

Передбачено, що архів є державною архівною установою Міністерства оборони України, він здійснює управління, методичну та інформаційну діяльність у сфері архівної справи у Міноборони і Генеральному штабі Збройних Сил України, інших органах військового управління, з'єднаннях, військових частинах, військових навчальних закладах, установах і організаціях Збройних Сил, на підприємствах, в установах та організаціях, що належать до сфери управління Міноборони та Збройних Сил України. Архів здійснює приймання, облік та зберігання документів Національного архівного фонду та інших документів Міноборони і Генерального штабу, військових частин (установ) та створює умови для користування цими документами. Зокрема, у ньому зберігаються документи НАФ 
та архівні документи тривалого (понад 10 років) зберігання 3 різними носіями інформації, що відображають діяльність Міноборони і Генерального штабу, військових частин (установ). Серед основних завдань архіву - надання організаційно-методичної допомоги Міноборони, ГШ, військовим частинам (установам) з питань роботи 3 документами, що тимчасово зберігаються у них, та 3 питань підготовки документів до передавання в Архів, проведення експертизи цінності документів з метою внесення їх до НАФ або вилучення 3 нього, виявлення унікальних документів, контроль за станом діловодства та архівної справи у МО і ГШ, військових частинах (установах).

Галузевий державний архів Міністерства оборони України зберігає у своїх фондах документальні джерела щодо історії російськоукраїнської війни. 32015 року до нього надходять на зберігання документи штабу Антитерористичної операції та штабу операції Об'єднаних сил на території Донецької та Луганської областей, а також військових частин, особовий склад яких брав участь у їх проведенні.

Висновки. Таким чином, говорячи про нормативно-правову базу щодо збереження документів та матеріалів російсько-української війни, слід звернути увагу на формування системного підходу у цьому питанні. Вжиття заходів, в тому числі і правотворчого характеру, щодо свідомого та несвідомого недопущення втрат такого роду історичних джерел, що містять надзвичайно цінний, а інколи і унікальний фактологічний багаж.

\section{Використані посилання}

Наказ Генерального штабу Збройних Сил Украӥни від 16.09.2013р. № 200. «Про затвердження Інструкиії з діловодства в Збройних Силах України» [online] Доступно: <https://zsu.at.ua/load/akti_ngsh_zsu/ nakaz_ ngsh_ zsu_ vid_ 16_09_2013_200_pro_zatverdzhennja_instrukciji_z_dilovodstva_v_zbrojnikh_silakh_ ukrajini/5-1-0-2> [Дата звернення 30 травня 2019].

Про Наиіональний архівний фонд та архівні установи. Закон України від 21 травня 2015p. № 316-VIII./Верховна Рада України. [online] Доступно: <https://zakon.rada.gov.ua/laws/show/3814-12> [Дата звернення 14 червня 2019].

Наказ Генерального штабу Збройних Сил Украӥни від 07.04.2017 p. № 124. «Про затвердження Інструкиії з діловодства в Збройних Силах України» 
[online] Доступно: <https://zsu.at.ua/load/akti_ngsh_zsu/nakaz_ngsh_zsu_vid_ 07_ 04_2017_124_pro_zatverdzhennja_instrukciji_z_dilovodstva_v_zbrojnikh_silakh_ukrajini/ 5-1-0-19> [Дата звернення 4 червня 2019].

Наказ Міністерства оборони Украӥни від 17.06.2013 р. № 4 «Про затвердження Переліку документів, щео утворюються в діяльності Міністерства оборони Украйни та Збройних Сил України, із зазначенням строків зберігання документів» [online] Доступно: 〈http://www.mil.gov.ua/content/other/mou _404_ 170613.pdf> [Дата звернення 5 червня 2019].

\section{References}

Order of the General Staff of the Armed Forces of Ukraine № 200, 16.09.2013, «On approval of the Instruction for office administrators in the Armed Forces of Ukraine», Available at: <https://zsu.at.ua/load/akti_ngsh_zsu/nakaz_ngsh_zsu_vid_ 16_09_2013_200_pro_zatverdzhennja_instrukciji_z_dilovodstva_v_zbrojnikh_silakh _ukrajini/5-1-0-2> [Accessed 30 May 2019] (ukr).

About the National Archival Fund and archival institutions. Law of Ukraine, 21 May 2015, № 316-VIII./Verkhovna Rada of Ukraine. Available at: <https:// zakon.rada.gov.ua/laws/show/3814-12> [Accessed 14 June 2019] (ukr).

Order of the General Staff of the Armed Forces of Ukraine № 124, 07.04.2017, «On approval of the Instruction for office administrators in the Armed Forces of Ukraine», Available at: <https://zsu.at.ua/ load/akti_ngsh_zsu/nakaz_ngsh_zsu_vid_ 07_04_2017_124_pro_zatverdzhennja_instrukciji_z_dilovodstva_v_zbrojnikh_silakh _ukrajini/5-1-0-19> [Accessed 4 June 2019] (ukr).

Order of The Ministry of Defense of Ukraine № 4, 17.06.2013, «On Approval of the List of Documents Formed of the Ministry of Defense of Ukraine and the Armed Forces of Ukraine activity, specifying the terms of documents storage», Available at: <http://www.mil.gov.ua/content/other/mou _404_ 170613.pdf> [Accessed 5 June 2019] (ukr).

\section{Turchak A., Nadraga M. \\ NORMATIVE AND LEGAL BASIS FOR THE PRESERVATION OF DOCUMENTS AND MATERIALS OF THE RUSSIAN-UKRAINIAN WAR}

Nowadays there is an urgent need to preserve historical sources to study the history of the recent Russian-Ukrainian war, a comprehensive objective study of its events, facts and phenomena. The source base for such historical research is extremely diverse and presentable. Media, television, radio and press, Internet resources, oral history sources and, most importantly, documentary complexes, in particular, office work materials of the military units and units of the Armed Forces of Ukraine are among the major source complexes.

The article deals with the analysis of the normative and legal basis in the field of documents preservation, covering the course of the Russian-Ukrainian war. One of the 
unique phenomena of social and political life is the media, which is considered as a historical source and a subject of the historical process. Internet resources as a historical source are the most widely used and available to the public. A significant layer of important and unique information is the reconstruction of the events of the war in the memories of its participants, in the materials of the interview by the method of "oral history". The main type of the documentary complexes that serve as a source for the study of the history of the war is the office work materials of the military units and the units of the Armed Forces of Ukraine, which are directly involved in the ATO and the OOF. One of these types of documents is a historical form - a document, which, in particular, reflects the military activity of the military unit, important events, a state of combat training, military discipline and other information. Talking about the normative and legal basis for the preservation of documents and materials of the Russian-Ukrainian war, we note it to be sufficient. However, we should pay attention to the formation of a systematic approach in this matter. Taking measures, including law-making ones, to consciously and unconsciously avoid the loss of such historical sources that contain extremely valuable and sometimes unique factual baggage, is of great importance.

Keywords: Russian-Ukrainian war, normative and legal basis, source base. 